MEDICAL ETHICS

\title{
The tension between self governance and absolute inner worth in Kant's moral philosophy
}

M Häyry

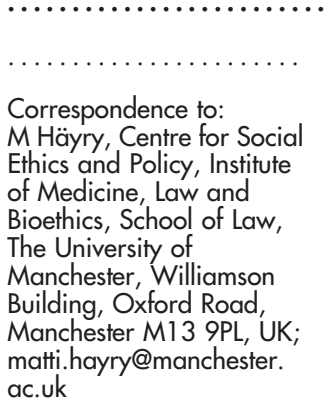

Received 11 July 2004

In revised form

24 January 2005

Accepted for publication

19 February 2005

J Med Ethics 2005;31:645-647. doi: 10.1136/jme.2004.010058

The concepts of autonomy as the self governance of individuals and dignity as the inner worth of human beings play an important role in contemporary bioethics. Since both notions are crucial to Immanuel Kant's moral theory, it would be tempting to think that Kantian ethics could ease the friction between the two concepts. It is argued in this paper, however, that this line of thought cannot be supported by Kant's original ideas. While he did make a conscious effort to bring autonomy and dignity together, his emphasis on the absolute inner worth of our collective humanity made it impossible for him to embrace fully the personal self determination of individuals, as it is usually understood in today's liberal thinking.
$\mathrm{T}$ he concepts of autonomy and dignity play a central role in contemporary discussions on bioethics. According to one popular view, personal autonomy, understood as the freedom of individuals to do, choose, and be whatever they want is the paramount ethical consideration in medicine, health care, and the life sciences. This creed is usually attributed to the adherents of the "liberal" or "utilitarian" traditions. ${ }^{1-7}$ According to an equally popular view, at least in Europe, however, considerations such as justice, solidarity, precaution, and especially dignity should in many cases take precedence over respect for individual freedom, as defined above. ${ }^{8-11}$ Although the clash is to a considerable extent artificial and verbal, ${ }^{12-15}$ the concepts of autonomy and dignity tend to be seen as antagonistic.

There is, however, a notable exception to this rule. At bioethical conferences and meetings many people advocate the idea that autonomy and dignity can, in fact, coexist in mutual harmony, and that genuinely liberal policies can incorporate prohibitions based on traditional accounts of human worth.

Depending on the definitions used, the first part of this dual claim can be perfectly true. If autonomy means freedom to do and to be whatever we want, and if dignity means that what we want is sacrosanct in self regarding matters, then there is no contradiction. ${ }^{16}$ Similarly, if autonomy means self guidance within the boundaries of the moral law, and if dignity means the presence of the moral law in our persons, the two are entirely compatible. These combinations mark the competing current notions of autonomy, which derive from the works of John Stuart Mill and Immanuel Kant. ${ }^{17-21}$

Problems arise, however, when the second part of the claim is introduced into discussions-when legislators or academics assume that a Millian concept of autonomy can be combined with a Kantian concept of dignity. One prominent example is the recent German debate on the use of human embryonic stem cell lines in research. ${ }^{22-25}$ In the legislative compromise that ensued, ${ }^{26}$ both Millian (politically liberal) and Kantian (morally conservative) reasons were happily paraded side by side. The underlying philosophical rationale, if any, might have been a conviction that Kant's ideas of personal self governance (autonomy) and absolute human worth (dignity) can somehow bridge the otherwise unsurpassable gap between political liberalism and moral conservatism in consistent law making.

In this paper, I aim to show that this conviction is false, by explicating Kant's own doctrines on self governance and absolute inner worth against the framework of the competing ideologies of his time. I will start by briefly describing two rival eighteenth century views that Kant tried to bring together. I will then go on to sketch the way in which he tried to do this, citing his definitions and characterisations of the close link between autonomy and dignity. The next step is to examine what exactly Kant lost, from the viewpoint of my inquiry, in the process of merging two arguably incompatible concepts. Finally, I will consider the lessons that can be learned from the inability of the Kantian model to unite the two views.

\section{THE COMPETING VIEWS KANT TRIED TO CONSOLIDATE}

In the eighteenth century, most philosophical debates in Europe had theological and religious underpinnings. The emerging discussion on the freedom and self governance of individuals was no exception. Philosophers were divided, according to their theological and religious views, into two warring camps, those of "intellectualism" and "voluntarism". My account of these follows closely J B Schneewind's pioneering work on the topic. ${ }^{27}$

The proponents of "intellectualism" (a creed associated with "epistemological rationalism") believed that people can, in the light of reason, understand what God, the creator of the world and its ultimate judge, thinks about morality. According to the traditional version of this view, ${ }^{28}{ }^{29}$ only a limited number of people actually possess this ability. Since, however, these privileged individuals can share their knowledge with other people, everybody can, in theory at least, find out what God expects of his creatures. This common moral understanding was seen as a prerequisite of justice, since it 
would be unfair to judge people on criteria of which they do not, and cannot, have knowledge.

The champions of "voluntarism" (a view linked with "epistemological empiricism"), by contrast, thought that human beings should not try to define, and thereby restrict, the judgments that God can or cannot make. ${ }^{30}$ As an all powerful being, God can do whatever he chooses-he can even change his moral commands at will. For instance, bigamy is currently forbidden, but it is perfectly feasible that under different circumstances God would condone it. Finite human beings are not supposed to stretch their intelligence in an attempt to guess what God's thoughts are. Whatever he demands or allows is right, and whatever he forbids is wrong. We may be able to feel or sense the rightness and wrongness of actions, but reason (or intellect) cannot help us in this task.

The emphasis given to the freedom of God's will in voluntarism coincided with the liberal political movement, in which the freedom of individuals was stressed. The value of human life was linked with the ability to make choices for oneself. ${ }^{31}$ Within the outcome oriented ethical version of the liberal doctrine, ${ }^{32}$ the idea that feelings and sensations can provide a guide to morally right action made pleasure and happiness the cornerstones of many ethical theories.

\section{HOW DID HE BRING THEM TOGETHER?}

Kant was familiar with both competing traditions, intellectualism and voluntarism, and he tried to combine them in his own philosophy. He was attracted to the view that human freedom and self government are somehow important to ethics and politics, but he also held that human beings ought to belong to the same moral community with God. His solution was to employ the intertwined concepts of autonomy and dignity.

Kant's primary concern was to show that morality, as the freedom to choose between right and wrong, is indeed possible in a world governed by material causes. To support his case, he introduced the distinction between the empirical world, which is causally determined, and the noumenal world, which is not. As bodily creatures, we belong to the empirical world, but as rational agents, we inhabit the noumenal sphere. Our morally practical reason, our noumenal part, is free to make its own laws, and to act in accordance with them, without paying unnecessary attention to the demands of the empirical body.

Since morality requires freedom, and freedom can be attributed only to our practical reason, or will, it follows that the only way to act morally is to obey the commands of the will. This is what Kant called autonomy. In his own words:

\section{Autonomy of the will is the property that the will has of being a law to itself. [Morality] is the relation of actions to the autonomy of the will[...]. That action which is compatible with the autonomy of the will is permitted; that which is not compatible is forbidden (Kant, ${ }^{18} \S \S 440$, 439, p 44).}

Kant believed that the demands of practical reason are the same on all rational beings. This provides us with a test for our moral principles. In order to act autonomously, we must act according to rules which could be autonomously chosen by any rational agent. The requirements of the moral law are, in other words, universal.

Autonomy of the will makes human beings equal to God in that we, too, can make our own laws. Can we, however, make these laws as we like? Would that not lead to a rule of rational human beings on a par with God? Surely that would be unacceptable. This is where Kant introduced the concept of dignity. In the empirical world, human beings are entities of little significance, and human feelings, desires, aspirations, inclinations, and likings do not amount to much. In Kant's words, however:

man as a person-that is, as the subject of a morally practical reason, is exalted above all price. For as such a one (homo noumenon) he is not to be valued merely as a means to the ends of other people, or even to his own ends, but is to be prized as an end in himself. This is to say, he possesses a dignity (an absolute inner worth) whereby he exacts the respect of all other rational beings in the world, can measure himself against each member of his species, and can esteem himself on a footing of equality with them (Kant, ${ }^{19} \S \S 434-5, \mathrm{p}$ 97).

By combining the ideas of autonomy and dignity in this way Kant was able to accommodate, to a certain extent at least, the main points of both voluntarism (the freedom of the will) and intellectualism (the rule of reason). The self regulation of the will ensured that a realm of human freedom exists, and the universality of practical reason made God and all his rational creatures equal in the domain of morality.

\section{WHAT DID HE LOSE IN THE PROCESS?}

The division of reality into the empirical and noumenal worlds rendered it, in the end, impossible for Kant to do justice to the self governance, or autonomy, of individuals, as they are seen in most of the liberal tradition. The autonomy of the will, as he defined it, and the dignity of humanity eventually belong to the noumenal world, not to the empirical sphere that people and their choices inhabit. They (autonomy and dignity) are not a part of our decision making as physical and psychological beings, but rather alien forces that we find in ourselves, and must respect. As Kant wrote:

[From] the fact that one is capable of [...] internal legislation and that the (physical) man feels himself compelled to venerate the (moral) man in his person, there must [...] follow exaltation and the highest self esteem. This is the feeling of one's inner worth (valor), according to which he is above all price (pretium) and possesses an inalienable dignity (dignitas interna), which inspires him with respect (reverentia) for himself (Kant, ${ }^{19} \S$ 436, p 98).

By the double meaning of the words "man", "one", and "he" in this passage (and others like it), Kant drew a sharp distinction between particular human beings (the empirical individuals who feel the respect and awe) and humanity in general (in our noumenal part), and denied the possibility of proper self governance in the light of individual (empirical) concerns.

The practical implication of this move is that when we respect autonomy and dignity in other people, as we should, we do not necessarily have to respect the actual empirical choices they make, however uncoerced and informed they are. According to Kant, it is against our humanity to take our own lives, or to give away or sell integral parts of our body (Kant, ${ }^{19} \S \S 422-3$, pp 82-4). This means that voluntary euthanasia and organ sale can be automatically ruled out as immoral. This conclusion is reached, however, at the expense of individual self governance, or "autonomy" as it is usually understood in present day ethical discussions.

(It is another question whether, within Kant's doctrine, we should or should not respect other people's actual choices in the sense that we should not constrain them, or coerce them, 
by legal restrictions or by the pressure of public opinion. This is not the question of this paper. It is clear, however, that people who oppose abortion, euthanasia, organ sales, or cloning can claim that those who disagree with them are immoral. The logic here is that since they have come to the conclusion that these practices are against the moral law, and since the moral law is universal, those who disagree with them must stand in violation of it.)

A further step toward dignity (as absolute inner worth) and away from autonomy (as self governance even in Kant's sense) is taken in standard Kantian analyses of reproductive decision making. Kant himself asserted that if a pregnant woman takes her own life, she also takes the life of another person, namely that of the unborn child (Kant, ${ }^{19} \S 422$, p 83). Since unborn children are not, however, "capable of internal legislation" (or rationality), the basis for respecting their dignity as human beings cannot be personhood, or morally practical subjectivity. There must be something else, maybe something like an eternal soul, which commands our respect for them, and makes suicide while pregnant, abortion, and possibly cloning morally condemnable. ${ }^{33}$

\section{WHAT CAN WE LEARN FROM THIS?}

Kant combined the basic tenets of intellectualism and voluntarism in the theological discussion of his time by arguing that while we know that reason is the basis of morality, we can have no empirical knowledge of the way practical reason works within us. As dignified rational beings, we are God's equals, but we cannot understand what this means, because the autonomy of the will, in God and in ourselves, is to us a mystery. One of the few things that we do know about this matter is that empirical phenomena like feelings, sensations, and inclinations are not autonomous, and should not therefore be relied upon in ethical decision making.

As a theological attempt to consolidate intellectualism and voluntarism, Kant's doctrine can have its merits, but it did not bring together, on equal terms, the related ethical theories of his time-or ours. The ability of human beings to make choices based on their own individual considerations, the standard starting point of liberal moral and political doctrines, never gained a decisive role in Kant's philosophy. Instead, the normative substance of his ethical model was derived from more traditional ideals concerning our collective humanity, as assigned to us by God.

The lesson to be learned from these considerations is, I believe, that autonomy and dignity, as these concepts are predominantly used in contemporary discussions, cannot be properly consolidated by appeals to Kant's moral philosophy. Kant did bring together autonomy and dignity in one sense, but the freedom of individuals to do or to be what they want did not have any normative role in his scheme. This means that, contrary to what is implied in, say, the German stem cell debate, Kant's ideas on self determination and inner moral worth do not provide a theoretical basis for legislative decisions which combine liberal political ideals and conservative moral principles.

None of this proves, or is intended to prove, anything about the legitimacy of liberal policies or conservative ethics. Nor does it confirm the supremacy of one or the other notion of autonomy. All it establishes is that people who prefer the Millian view on autonomy are not best positioned to use Kantian considerations of dignity as a part of their ethical and political arguments.

\section{ACKNOWLEDGEMENTS}

An early version of this paper was presented at the 21 st World Congress of Philosophy, in Istanbul, Turkey, 11-17 June 2003. The article was produced as a part of the following projects: Ethical, Legal and Social Aspects of Human Genetic Databases: A European Comparison (ELSAGEN), financed between 2002 and 2004 by the European Community (QLG6-CT-2001-00062); Public Policies, Law and Bioethics: A Framework for Producing Public Health Policy Across the European Union by Examining Concepts of European and Universal Ethical Standards (EuroPHEN), financed between 2003 and 2006 by the European Community (QLRT-2001-02320), and Ethical and Social Aspects of Bioinformatics (ESABI), financed between 2004 and 2007 by the Academy of Finland (SA 105139). My thanks are due to these institutions for their support, to the reviewers of the journal for their useful critical comments, and to Peter Herissone-Kelly for checking my English.

\section{REFERENCES}

1 Beauchamp TL, Childress JF. Principles of biomedical ethics [5th ed]. New York: Oxford University Press, 2000.

2 Singer P. Practical ethics [2nd ed]. Cambridge: Cambridge University Press, 1993.

3 Gillon R. Philosophical medical ethics. Chichester: John Wiley \& Sons, 1985.

4 Harris J. The value of life: an introduction to medical ethics. London: Routledge, 1985.

5 Engelhardt HT Jr. The foundations of bioethics [2nd ed]. New York: Oxford University Press, 1996.

6 Rachels J. The elements of moral philosophy [4th ed]. New York: McGraw-Hill Inc, 2003.

7 Buchanan A, Brock DW, Daniels N, et al. From chance to choice: genetics and justice [2nd ed]. New York: Cambridge University Press, 2002.

$8 \mathrm{Holm} \mathrm{S}$. Not just autonomy-the principles of American biomedical ethics. J Med Ethics 1995;21:332-8.

9 Houtepen R, ter Meulen R, eds. Solidarity in health care [special issue]. Health Care Anal 2000;8:329-411.

10 Kaiser $M$, ed. The precautionary principle and its implications for science [special issue]. Foundations of Science 1997;2:201-341.

11 Rendtorff JD, Kemp P, eds. Basic ethical principles in European bioethics and biolaw [vols 1 and 2]. Copenhagen and Barcelona: Centre for Ethics and Law \& Institut Borja de Bioètica, 2000.

12 Häyry $M$. European values in bioethics: why, what, and how to be used? Theor Med Bioeth 2003;24:199-214.

13 Häyry M. Another look at dignity. Camb Q Healthc Ethics 2004;13:7-14.

14 Häyry M. Precaution and solidarity. Camb Q Healthc Ethics 2005;14:199-206.

15 Häyry M, Takala T. American principles, European values, and the mezzanine rules of ethical genetic data banking. In: Árnason V, Árnason G, Chadwick $R$, et al. The ethics and governance of human genetic databases. Cambridge: Cambridge University Press (forthcoming)).

16 Häyry M. Prescribing cannabis: freedom, autonomy, and values. J Med Ethics 2004;30:333-6.

17 Mill JS. On liberty, On liberty and the subjection of women. Ware, Hertfordshire: Wordsworth, 1999.

18 Kant I. Grundlegung zur Metaphysic der Sitten, Ethical philosophy [2nd ed] [trans Ellington JW]. Indianapolis and Cambridge: Hackett Publishing Company, 1994.

19 Kant I. Metaphysische Anfangsgründe der Tugendlehre, Ethical philosophy [2nd ed] [trans Ellington JW]. Indianapolis and Cambridge: Hackett Publishing Company, 1994.

20 Takala T, Häyry M. Genetic ignorance, moral obligations and social duties. J Med Philos 2000;25:107-13.

21 Taylor JC, ed. Personal autonomy: new essays on personal autonomy and its role in contemporary moral philosophy. Cambridge: Cambridge University Press, 2005.

22 Heinemann T, Honnefelder L. Principles of ethical decision making regarding embryonic stem cell research in Germany. Bioethics 2002;16:530-43.

23 Romeo-Casabona CM. Embryonic stem cell research and therapy: the need for a common European legal framework. Bioethics 2002;16:557-67.

24 Oduncu FS. Stem cell research in Germany: ethics of healing v human dignity. Med Health Care Philos 2003;6:5-16.

25 Takala T, Häyry M. Benefiting from past wrongdoing, human embryonic stem cell lines, and the fragility of the German legal position. In: Harris J, ed. The ethics of stem cell research. Oxford: Oxford University Press (forthcoming)).

26 Deutscher Bundestag. Entwurf eines Gesetzes zur Sicherstellung des Embryonenschutzes im Zusammenhang mit Einfuhr und Verwendung menschlicher embryonaler Stammzellen (Stammzellgesetz-StZG). Berlin: Bundestagsdrucksache 14/8394, 2002 (in German)).

27 Schneewind JB. The invention of autonomy: a history of modern moral philosophy. Cambridge: Cambridge University Press, 1998.

28 Aquinas T. In:, Sigmund PE, ed and trans. St Thomas Aquinas on politics and ethics. New York and London: W W Norton \& Company, 1988.

29 Aquinas T. In: Baumgarth WP, Regan RJ, eds. Saint Thomas Aquinas on law, morality, and politics. Indianapolis and Cambridge: Hackett Publishing Company, 1988.

30 Scotus D. In:, Allan B, Wolter AB, eds and trans. Duns Scotus on the will and morality. Washington, DC: The Catholic University of America Press, 1986.

31 Locke J. Two treatises of government. Cambridge: Cambridge University Press, 1960.

32 Häyry M. Liberal utilitarianism and applied ethics. London and New York: Routledge, 1994.

33 Häyry M. Philosophical arguments for and against human reproductive cloning. Bioethics. 2003;17: 447-59 at $458 \mathrm{n} 22$ ). 